\title{
Skin Organogenesis and Dysmorphogenetic Factors in Skin Diseases (Review)
}

\author{
DOI: $10.17691 / \mathrm{stm} 2018.10 .4 .23$
}

Received December 22, 2017

N.V. Yaglova, MD, DSc, Head of the Laboratory of Endocrine System Development 1 ,

S.S. Obernikhin, MD, DSc, Senior Researcher, Laboratory of Endocrine System Development ${ }^{1 ;}$

D.A. Tsomartova, MD, PhD, Associate Professor, Department of Histology, Cytology and Embryology2; Researcher, Laboratory of Endocrine System Development';

M.J. Ivanova, MD, PhD, Associate Professor, Department of Histology, Cytology and Embryology2;

N.L. Kartashkina, MD, PhD, Associate Professor, Department of Histology, Cytology and Embryology2; E.V. Chereshneva, MD, PhD, Senior Lecturer, Department of Histology, Cytology and Embryology²

${ }^{1}$ Research Institute of Human Morphology, 3 Tsurupa St., Moscow, 117418, Russia;

${ }^{2}$ I.M. Sechenov First Moscow State Medical University (Sechenov University), 8/2 Trubetskaya St., Moscow, 119991, Russia

The study of the epidermis and derma histogenesis, including its epigenetic regulation, is an actively developing field of histology and embryology. The results of the study can elucidate the mechanisms of pathogenesis of some skin diseases of unknown etiology. Wnt signaling is a key regulator of the main morphogenetic processes - cell proliferation and differentiation. Downstream of Wnt signaling is carried out by canonical and non-canonical pathways. Impairments of Wnt signaling in prenatal and postnatal development lead to degenerative and tumor diseases of the skin and hair.

Clinical manifestations of the prenatal disorders of skin development epigenetic regulation in the period may appear long after the birth. Identification of factors that disturb the regulation of morphogenetic processes is an important task for investigators. It was found out that activation of the mother's immune system in the early pregnancy resulted in the development of transient alopecia in the offspring of mice. There was the correlation established between the disorders of epidermal and dermal histogenesis and alopecia as well as the development of regional dysmorphogenetic changes in the skin, which indicate the need to study the rates and features of skin development in various parts of the body.

Key words: skin; hair follicle; Wnt signaling; $\beta$-catenin; morphogenesis; skin diseases; skin tumors; alopecia.

\section{Introduction}

Among the diseases of skin and its appendages there are mostly nosologic disorders of unknown etiology and understudied pathogenesis [1-7]. The achievements of modern embryology, histology, and molecular biology make a considerable input into the understanding of epidermis and derma histogenesis mechanisms and allow targeted investigation of the role of epigenetic regulation mechanisms of morphogenetic process as their impairment is underlying some skin diseases [8, 9]. Regulation of intracellular signal pathways which manage various morphogenesis processes, such as proliferation, differentiation, migration and apical-basal polarization of epidermis cells, is determined by secreted Wnt proteins, primarily by $\beta$-catenin, which is an activator of canonic Wnt signaling [10-15].

The role of Wnt signaling in prenatal skin development

It is known that after gastrulation the surface of an embryo is represented by one layer of ectoderm which then forms a neural tube and skin ectoderm [16]. When there is no signal of fibroblast growth factor the ectoderm cells start expressing bone morphogenetic proteins and are determined to form epidermis. And on the contrary, the nervous system development occurs when ectoderm can accept and modify the signals activating fibroblast growth factor and then inhibiting bone morphogenetic proteins [17-21]. Activity of bone morphogenetic proteins plays a crucial role in the formation of a border area between skin ectoderm and neuroectoderm [22]. The key regulator of divergence is Wnt signaling which blocks an ability of ectoderm to react to fibroblast growth factor.

Wnt signaling can be transduced by canonic and noncanonic pathways [23-30]. Non-canonic transduction of Wnt signaling happens via $\mathrm{G}$ proteins, such as Rho/ Rac, which control cell polarity by remodeling an active cytoskeleton or by changing intracellular concentration of calcium ions [24, 31]. In the canonic Wnt pathway the key transcription co-activator and transmitter of an extracellular signal activating target genes is $\beta$-catenin. $\beta$-catening transcription activator is stabilized when Wnt

Corresponding author: Natalya V. Yaglova, e-mail: yaglova@mail.ru 
is stimulated, then it penetrates the nucleus and binds with TCF/LEF1 factor ( $T$ cell factor/lymphoid enhancer factor 1) activating Wnt-sensitive target genes [11-13].

There are several different Wnt proteins and receptors in the vertebrates, and their expression in time and space is regulated during the development $[10,32]$. It is highly probable that one Wnt protein activates a combination of several signal cascades which can act independently or together. Addition of a greater number of complexity levels, co-factors, secreted antagonists and co-receptors of Wnt signal transmission modulates both canonic and non-canonic actions. It is known that non-canonic Wnt pathways can inhibit signal connection that depends on $\beta$-catenin. However, the mechanism underlying this inhibition is still unknown. Possible explanations include competition of Wnt ligands for binding with their receptors [33], suppression of $\beta$-catenin with E3ubiquitin of Siah2 ligase [34] or inhibition of transcription activity of Wnt/ $\beta$-catenin signaling via TAK1-NLK (TGF$\beta$-activated kinase 1 and nemo-like kinase)-mediated phosphorylation of $\mathrm{T}$ cell factors [35].

At early stages of skin development dynamic cross signals between embryonic epidermis and derma occur. The connection between the tissues mediates the formation of a basal membrane, epidermis stratification and induction of hair follicles (HF) [36]. The cells are differentiated into keratinocytes and form a basal layer of the embryonic epidermis. Keratinocytes in the newly formed embryonic basal layer substitute for 8/18 type keratin expression for $5 / 14$ types of keratin [37]. At the initial stage of epidermal stratification the basal cells form a transient layer called periderm which protects these cells from the constant effect of amniotic fluid [38]. The next layer of the epidermis formed between the basal layer and the periderm is called an intermediate layer, and its development is connected with asymmetric division of epidermal basal cells [39]. At the molecular level the process of epidermal stratification is organized by several transcription regulators and signal pathways [40-42]. When stratification program is completed, the epidermis consists of an internal layer of basal cells with a proliferative potential and suprabasal layers of differentiated cells.

\section{The role of Wnt signaling in the formation and development of a hair follicle}

HF morphogenesis includes the following three main stages: formation of hair placode, organogenesis and cytodifferentiation [43, 44]. The consequent events during morphogenesis are regulated by signals transmitted between the derma and epidermis $[45,46]$. Wnt pathway is considered the main regulator among all these signals.

Before the formation of placode skin fibroblasts get Wnt signals from the epidermis causing aggregation of epidermal basal cells which results in placode formation [47-50]. Notably, HF induction patterns depend on the competition between slowly diffusing Wnt ligands and faster diffused Wnt inhibitors [51].

After initial induction a developing placode produces Wnt ligands for the induction of underlying fibroblasts forming dermal condensate [52]. At the same time a placode is continuously growing, penetrating the derma layer in the form of invaginations and then it is bound with dermal condensate forming the first structure of HF organogenesis - the first hair lineage. Epidermal cells proceed penetrating into the derma and form a multilayer prolonged column named hair strand. Meanwhile dermal condensate becomes a spherical dermal papilla. The hair strand is thickened at the lower end to form a hair bulb. When the primary follicle grows into the hair strand, various epidermal layers are visualized and a hair shaft appears. As HF growth reached the subcutaneous layer, the program of cytodifferentiation starts. At this stage the dermal papilla becomes thinner and closes completely, a sebaceous follicle starts being formed in the upper part of HF. Then a fully formed hair shaft appears above the hair surface and HF reaches its maximum length [43]. Different stages of HF follicles are easy to identify according to their morphological and biochemical specific properties [53].

Inside each mature HF there are seven concentric rings of terminally differentiated cells which are derived from the cell matrix. Each ring had a specific ultrastructure. Transmission of Wnt/ $\beta$-catenin signaling is first regulated evenly in the upper layer of the derma and then focally both in the hair placode and in the underlying dermal condensate [54-57]. When signalization of Wnt/ $\beta$-catenin switches off, the formation of HF is blocked [58-60]. Excessive expression of a stable form of $\beta$-catenin or LEF1 induces the formation of a HF de novo $[61,62]$.

\section{Wnt signaling in hair follicles in the postnatal period}

In the postnatal skin mature HF are exposed to repeated growth cycles [63]. Like in HF morphogenesis initiation of a new growth phase and as a consequence proliferation, differentiation and regress of a follicle are connected with wide interaction between dermal and epidermal cells [64]. Many studies [65-72] suppose that the same signal pathways which are active during HF embryogenesis are repeatedly used in cyclic processes occurring in a postnatal HF. In particular, it was shown that $W n t / \beta$-catenin signaling plays an important role at the several stages of hair development beginning from the earliest stages of transition from resting to growth and differentiation of a HF.

In the postnatal period the epidermis is continuously regenerating due to proliferation of the basal cells of interfollicular epidermis (IE). This IE cell pool gives birth to the cells which will be differentiated into suprabasal cells migrating into the overlying layers. During this process a number of epidermal cells remains 
constant as the number of newly generated cells exactly compensates for the number of cells which are differentiated or die [73].

To explain how stem cells of the basal layer replenish IE cells, the following two models were suggested: hierarchical and stochastic [74]. A hierarchical model states that a slow cycle of stem cells occurring in each epidermal proliferative IE unit generate shortliving transient amplifying cells which later on give birth to ifferentiated cells. A stochastic model means that the ancestors of IE basal layer have an equal potential for generation of daughter cells which remain as predecessors or are differentiated into suprabasal cells [75].

In the developing epidermis a high level of Wnt/ $\beta$-catenin signal transmission is necessary for $\mathrm{HF}$ induction. Weakening of these signals from the epidermis worsens HF formation but does not affect IR integrity [76]. Notably, the loss of $\beta$-catenin in IE even causes its hyperproliferation [77]. Nevertheless the studies of cell line tracing show the presence of signal activity of Wnt/ $\beta$-catenin in basal cells of glabrous skin. When these cells run out of $\beta$-catenin, proliferative capacity of the epidermis is sharply decreased [78, 79]. Different results of epidermis proliferation can be partially explained by fundamental differences between the epidermis of hairy skin and glabrous skin as it is believed that epidermal hyperproliferation of hairy skin can be partially resulted from an inflammatory response to HF decay [80].

\section{The role of impairment of $\mathrm{Wnt} / \beta$-catenin signaling in pathogenesis of skin diseases}

Taking into consideration the important role of $\mathrm{Wnt} / \mathrm{\beta}$ catenin signal transmission it is easy to understand the impairment of the activity of signal pathways can lead to congenital abnormalities and diseases [8184]. Excessive activation of transmission of these signals causes different tumors in transgenic mice. In HF constitutive expression of stabilized $\beta$-catenin leads to the formation of pilomatricomas which are densely packed benign tumors with the center from the cells of hair strand surrounded by matrix cells or trichofolliculomas which regress when the pathway activation stops [82]. Many human pilomatricomas also contain mutations stabilizing $\beta$-catenin [85]. On the contrary when Wnt/ $\beta$-catenin signaling in transgenic mice is suppressed, tumors of sebaceous follicles are developing more frequently $[59,86]$. It also happens in human tumors as one third of them contain mutations which block $\beta$-catenin binding [87].

The studies showed that unfavorable environmental condition during pregnancy can have a negative impact on the development and functioning of various organs of the offspring. These manifestations can have longterm consequences and even fixe as a hereditary quality [88-90]. Impaired expression of $\beta$-catenin in prenatal and postnatal development mediates dysmorphogenetic disorders and can be the cause of pathogenesis of a number of diseases (see the Figure). Thus, reduced function of $\beta$-catenin in the embryonic period of development can lead to the reduced proliferation of epithelial cells of a hair bulb [77], HF regeneration impairment [91] and reduced proliferation of keratinocytes of glabrous skin $[52,87]$. And on the contrary, recovery of $\beta$-catenin function in the embryonic period in the postnatal period leads to an early transition into anagen [92, 93], hyperplasia and HF cyst formation [56].

Congenital HF defects are rather rare and are usually caused by mutations in genes coding keratins and other structural proteins [94]. To the acquired defects one refers alopecia which can have inflammatory and non-

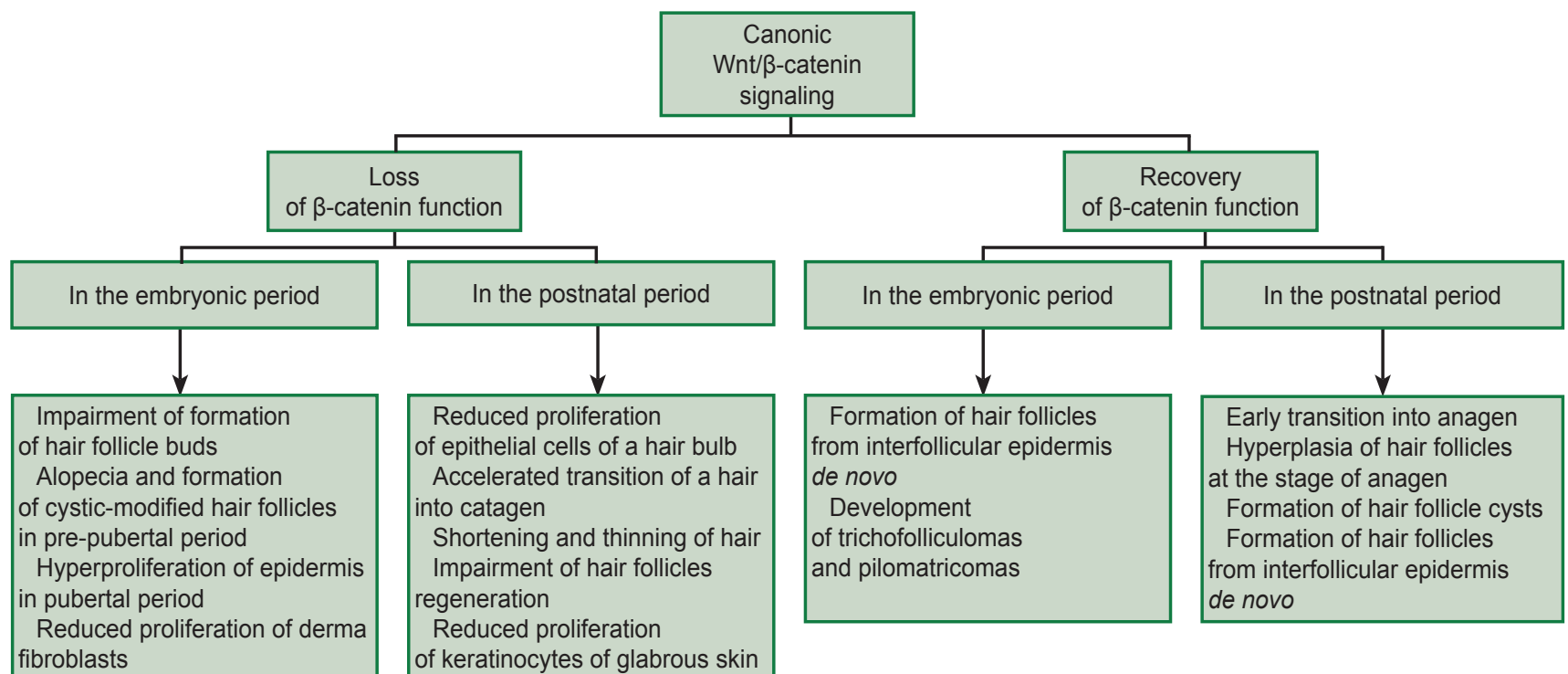

Dysmorphogenetic consequences of impairments of canonic Wnt/ $\beta$-catenin signaling in the epidermis and hair follicles in mice 
inflammatory etiology [44, 95, 96]. Inflammatory alopecia can result from a bacterial infection, dermatophytosis, and bites of external parasites, autoimmune diseases, injuries or toxin effects (for instance, mercury, thallium or iodine). The reason for non-inflammatory diseases which lead to alopecia is the deficit of nutrients, endocrine disorders, childbirth, anemia and intake of cytostatic medications [97].

One of the important tasks is to determine specific factors that can change epigenetic regulation in the prenatal and postnatal periods of human ontogenesis. It was found out [98] that short-term activation of the maternal immune system at the early pregnancy leads to transient hereditary alopecia in the offspring and that impairment of the development of skin and its integumentary structures is caused by the effect of cytokines produced by the cells of the mother's immune system. The studies showed that on day 17 of postnatal development the offspring got alopecia in the area of the back and abdomen and in several days it turned into complete loss of fur in these areas. Histological investigation of the skin in these areas showed cysto-widened HF containing broken hair shafts and reduced HF number, slowed formation of connective components of derma, lowered number of cells in the derma, increased number of neutrophils in the derma in alopecia. The head and paws retained fur, and in these areas the derma structure was characterized by a high amount of amorphous component of intercellular matrix. The fur in these animals was restored along with thickening of the derma and the amount of amorphous component of intercellular matrix in them and it confirms a pathogenic role of derma immaturity in hair growth disorder [99, 100].

The most probable mechanism of reduction of HF number in the offspring skin during activation of the mother's immune system is impairment of Wnt signals providing HF formation. The lack of changes in the head skin shows regional differences in the regulation of the skin histogenesis. There are findings that if there common stages of formation of the epidermis and derma, thickening of the epidermis and increase in the number of its layers on the head skin happens faster than in body skin due to different rates of the main morphogenetic processes - proliferation and apoptosis [101-103]. Consequently, impairments of transcription regulation of morphogenetic processes in the embryo skin can be not general, but local.

\section{Conclusion}

Investigations of regulation of morphogenetic processes in the skin show an important role of epigenetic regulation both morphogenetic and dysmorphogenetic factors. Impairments of canonic Wnt signaling in the prenatal period can be underlying pathogenesis of different diseases of the skin and its appendages of tumor and non-tumor character.
The findings of many works show that a specific feature of impairments of epigenetic regulation of skin organogenesis in the prenatal period can be longterm clinical manifestations in the postnatal period. These findings prove the need for further search of the regulation impairment causes and their consideration in patients' medical history as possible etiological factors of a number of skin diseases.

Funding. The study was not funded by any sources.

Conflict of interest. The authors confirm the absence of conflicts of interest that could influence their work.

\section{References}

1. Moretta G., De Luca E.V., Di Stefani A. Management of refractory pityriasis rubra pilaris: challenges and solutions. Clin Cosmet Investig Dermatol 2017; 10: 451-457, https://doi. org/10.2147/ccid.s124351.

2. Govoni M., Bortoluzzi A., Rossi D., Modena V. How I treat patients with adult onset Still's disease in clinical practice. Autoimmun Rev 2017; 16(10): 1016-1023, https://doi. org/10.1016/j.autrev.2017.07.017.

3. Pereira M.P., Ständer S. Chronic pruritus: current and emerging treatment options. Drugs 2017; 77(9): 999-1007, https://doi.org/10.1007/s40265-017-0746-9.

4. van Geel N., Speeckaert R. Segmental vitiligo. Dermatol Clin 2017; 35(2): 145-150, https://doi.org/10.1016/j. det.2016.11.005

5. Takeshita J., Grewal S., Langan S.M., Mehta N.N., Ogdie A., Van Voorhees A.S., Gelfand J.M. Psoriasis and comorbid diseases: epidemiology. J Am Acad Dermatol 2017; 76(3): 377-390, https://doi.org/10.1016/j.jaad.2016.07.064.

6. Perera E., Yip L., Sinclair R. Alopecia areata. Curr Probl Dermatol 2015; 47: 67-75, https://doi.org/10.1159/000369406.

7. Redler S., Messenger A.G., Betz R.C. Genetics and other factors in the aetiology of female pattern hair loss. Exp Dermatol 2017; 26(6): 510-517, https://doi.org/10.1111/ exd.13373.

8. Miranda B.H., Charlesworth M.R., Tobin D.J., Sharpe D.T., Randall V.A. Androgens trigger different growth responses in genetically identical human hair follicles in organ culture that reflect their epigenetic diversity in life. FASEB $J$ 2018; 32(2): 795-806, https://doi.org/10.1096/fj.201700260rr.

9. Wilms C., Kroeger C.M., Hainzl A., Banik I., Bruno C., Krikki I., Farsam V., Wlaschek M., Gatzka M.V. MYSM1/2ADUB is an epigenetic regulator in human melanoma and contributes to tumor cell growth. Oncotarget 2017; 8(40): 67287-67299, https://doi.org/10.18632/oncotarget.18617.

10. Logan C.Y., Nusse R. The Wnt signaling pathway in development and disease. Annu Rev Cell Dev Biol 2004 20: 781-810, https://doi.org/10.1146/annurev.cellbio.20.010403. 113126.

11. Nusse R. Wnt signaling and stem cell control. Cell Research 2008; 18(5): 523-527, https://doi.org/10.1038/ cr.2008.47.

12. Clevers $H$. ., Nusse R. Wnt/beta-catenin signaling and disease. Cell 2012; 149(6): 1192-1205, https://doi.org/10.1016/j. cell.2012.05.012.

13. Clevers $\mathrm{H}$. Wnt/beta-catenin signaling in development and disease. Cell 2006; 127(3): 469-480, https://doi. org/10.1016/j.cell.2006.10.018. 
14. van Amerongen R., Nusse R. Towards an integrated view of Wht signaling in development. Development 2009; 136(19): 3205-3214, https://doi.org/10.1242/dev.033910.

15. Polakis $P$. The many ways of Wnt in cancer. Curr Opin Genet Dev 2007; 17(1): 45-51, https://doi.org/10.1016/j. gde.2006.12.007.

16. Hardy M.H. The secret life of the hair follicle. Trends Genet 1992; 8(1): 55-61, https://doi.org/10.1016/0168-9525 (92)90044-5.

17. Stern C. Neural induction: old problem, new findings, yet more questions. Development 2005; 132(9): 2007-2021, https://doi.org/10.1242/dev.01794.

18. Wilson S.I., Rydström A., Trimborn T., Willert K., Nusse R., Jessell T.M., Edlund T. The status of Wnt signalling regulates neural and epidermal fates in the chick embryo. Nature 2001; 411: 325-330, https://doi.org/10.1038/35077115.

19. Harland R. Neural induction. Curr Opin Genet Dev 2000; 10(4): 357-362, https://doi.org/10.1016/s0959-437x (00)00096-4.

20. Kobielak K., Stokes N., de la Cruz J., Polak L., Fuchs E. Loss of a quiescent niche but not follicle stem cells in the absence of bone morphogenetic protein signaling. Proc Natl Acad Sci USA 2007; 104(24): 10063-10068, https://doi. org/10.1073/pnas.0703004104.

21. Fuchs E. Scratching the surface of skin development. Nature 2007; 445(7130): 834-842, https://doi.org/10.1038/ nature05659.

22. Streit A. Early development of the cranial sensory nervous system: from a common field to individual placodes. Dev Biol 2004; 276(1): 1-15, https://doi.org/10.1016/j. ydbio.2004.08.037.

23. Angers S., Moon R.T. Proximal events in Wnt signal transduction. Nat Rev Mol Cell Biol 2009; 10(7): 468-477, https://doi.org/10.1038/nrm2717.

24. Seifert J.R.K., Mlodzik M. Frizzled/PCP signalling: a conserved mechanism regulating cell polarity and directed motility. Nat Rev Genet 2007; 8(2): 126-138, https://doi. org/10.1038/nrg2042.

25. Wang J., Sinha T., Wynshaw-Boris A. Wnt signaling in mammalian development: lessons from mouse genetics. Cold Spring Harb Perspect Biol 2012; 4(5): a007963, https://doi. org/10.1101/cshperspect.a007963.

26. Bayly R., Axelrod J.D. Pointing in the right direction: new developments in the field of planar cell polarity. Nat Rev Genet 2011; 12(6): 385-391, https://doi.org/10.1038/nrg2956.

27. Stoick-Cooper C.L., Moon R.T., Weidinger G. Advances in signaling in vertebrate regeneration as a prelude to regenerative medicine. Genes Dev 2007; 21(11): 1292-1315, https://doi.org/10.1101/gad.1540507.

28. Zallen J.A. Planar polarity and tissue morphogenesis. Cell 2007; 129(6): 1051-1106, https://doi.org/10.1016/j.cell. 2007.05.050.

29. Lai S.L., Chien A.J., Moon R.T. Wnt/Fz signaling and the cytoskeleton: potential roles in tumorigenesis. Cell Res 2009; 19(5): 532-545, https://doi.org/10.1038/cr.2009.41.

30. Simons M., Mlodzik M. Planar cell polarity signaling: from fly development to human disease. Annu Rev Genet 2008; 42: 517-540, https://doi.org/10.1146/annurev.genet.42. 110807.091432

31. Kohn A.D., Moon R.T. Wnt and calcium signaling: $\beta$-catenin-independent pathways. Cell Calcium 2005; 38(3-4): 439-446, https://doi.org/10.1016/j.ceca.2005.06.022.

32. Komiya Y., Habas R. Wnt signal transduction pathways.
Organogenesis 2008; 4(2): 68-75, https://doi.org/10.4161/ org.4.2.5851.

33. Grumolato L., Liu G., Mong P., Mudbhary R., Biswas R., Arroyave R., Vijayakumar S., Economides A.N., Aaronson S.A. Canonical and noncanonical Wnts use a common mechanism to activate completely unrelated coreceptors. Genes Dev 2010; 24(22): 2517-2530, https://doi.org/10.1101/gad.1957710.

34. Topol L., Jiang X., Choi H., Garrett-Beal L., Carolan P.J., Yang Y. Wnt-5a inhibits the canonical Wnt pathway by promoting GSK-3-independent beta-catenin degradation. J Cell Biol 2003; 162(1): 899-908, https://doi.org/10.1083/jcb.200303158.

35. Ishitani T., Ninomiya-Tsuji J., Nagai S., Nishita M., Meneghini M., Barker N., Waterman M., Bowerman B., Clevers H., Shibuya H., Matsumoto K. The TAK1-NLK-MAPKrelated pathway antagonizes signalling between beta-catenin and transcription factor TCF. Nature 1999; 399(6738): 798802, https://doi.org/10.1038/21674.

36. Candi E., Schmidt R., Melino G. The cornified envelope: a model of cell death in the skin. Nat Rev Mol Cell Biol 2005; 6(4): 328-340, https://doi.org/10.1038/nrm1619.

37. Byrne C., Tainsky M., Fuchs E. Programming gene expression in developing epidermis. Development 1994; 120(9): 2369-2383.

38. M'Boneko V., Merker H.J. Development and morphology of the periderm of mouse embryos (days 9-12 of gestation). Acta Anat 1988; 133(4): 325-336, https://doi. org/10.1159/000146662.

39. Lechler T., Fuchs E. Asymmetric cell divisions promote stratification and differentiation of mammalian skin. Nature 2005; 437(7056): 275-280, https://doi.org/10.1038/ nature03922.

40. Koster M.I., Roop D.R. Mechanisms regulating epithelial stratification. Annu Rev Cell Dev Biol 2007; 23(1): 93-113, https://doi.org/10.1146/annurev.cellbio.23.090506.123357.

41. Fuchs E., Raghavan S. Getting under the skin of epidermal morphogenesis. Nat Rev Genet 2002; 3(3): 199209, https://doi.org/10.1038/nrg758.

42. Liu S., Zhang H., Duan E. Epidermal development in mammals: key regulators, signals from beneath, and stem cells. Int J Mol Sci 2013; 14(6): 10869-10895, https://doi. org/10.3390/ijms140610869.

43. Schmidt-Ullrich R., Paus R. Molecular principles of hair follicle induction and morphogenesis. Bioessays 2005; 27(3): 247-261, https://doi.org/10.1002/bies.20184.

44. Paus R., Müller-Röver S., Van Der Veen C., Maurer M., Eichmüller S., Ling G., Hofmann U., Foitzik K., Mecklenburg L., Handjiski B. Comprehensive guide for the recognition and classification of distinct stages of hair follicle morphogenesis. J Invest Dermatol 1999; 113(4): 523-532, https://doi. org/10.1046/j.1523-1747.1999.00740.x.

45. Zhu X.J., Liu Y., Dai Z.M., Zhang X., Yang X., Li Y., Qiu M., Fu J., Hsu W., Chen Y., Zhang Z. BMP-FGF signaling axis mediates Wnt-induced epidermal stratification in developing mammalian skin. PLoS Genet 2014; 10(10): e1004687, https://doi.org/10.1371/journal.pgen.1004687.

46. Popp T., Steinritz D., Breit A., Deppe J., Egea V., Schmidt A., Gudermann T., Weber C., Ries C. Wnt5a/betacatenin signaling drives calciuminduced differentiation of human primary keratinocytes. J Invest Dermatol 2014; 134(8): 2183-2191, https://doi.org/10.1038/jid.2014.149.

47. Hu B., Lefort K., Qu W., Nguyen B.C., Rajaram R.D., Castillo E., He F., Chen Y., Angel P., Brisken C., Dotto G.P. Control of hair follicle cell fate by underlying mesenchyme 
through a CSL-Wnt5a-FoxN1 regulatory axis. Genes Dev 2010; 24(14): 1519-1532, https://doi.org/10.1101/gad.1886910.

48. Guo N., Hawkins C., Nathans J. Frizzled6 controls hair patterning in mice. Proc Natl Acad Sci USA 2004; 101(25): 9277-9281, https://doi.org/10.1073/pnas.0402802101.

49. Devenport D., Fuchs E. Planar polarization in embryonic epidermis orchestrates global asymmetric morphogenesis of hair follicles. Nat Cell Biol 2008; 10(11): 1257-1268, https://doi. org/10.1038/ncb1784.

50. Devenport D., Oristian D., Heller E., Fuchs E. Mitotic internalization of planar cell polarity proteins preserves tissue polarity. Nat Cell Biol 2011; 13(8): 893-902, https://doi. org/10.1038/ncb2284.

51. Sick S., Reinker S., Timmer J., Schlake T. WNT and DKK determine hair follicle spacing through a reaction-diffusion mechanism. Science 2006; 314(5804): 1447-1450, https://doi. org/10.1126/science.1130088.

52. Chen D., Jarrell A., Guo C., Lang R., Atit R. Dermal beta-catenin activity in response to epidermal Wnt ligands is required for fibroblast proliferation and hair follicle initiation. Development 2012; 139(8): 1522-1533, https://doi. org/10.1242/dev.076463.

53. Müller-Röver S., Handjiski B., van der Veen C., Eichmüller S., Foitzik K., McKay I.A., Stenn K.S., Paus R. A comprehensive guide for the accurate classification of murine hair follicles in distinct hair cycle stages. J Invest Dermatol 2001; 117(1): 3-15, https://doi.org/10.1046/j.0022202x.2001.01377.x.

54. Cui C.Y., Kunisada M., Piao Y., Childress V., Ko M.S., Schlessinger D. Dkk4 and Eda regulate distinctive developmental mechanisms for subtypes of mouse hair. PLoS One 5(4): e10009, https://doi.org/10.1371/journal.pone.0010009.

55. Millar S.E. Molecular mechanisms regulating hair follicle development. J Invest Dermatol 2002; 118(2): 216-225, https:// doi.org/10.1046/j.0022-202x.2001.01670.x.

56. DasGupta R., Fuchs E. Multiple roles for activated LEF/ TCF transcription complexes during hair follicle development and differentiation. Development 1999; 126(20): 4557-4568.

57. Zhou P., Byrne C., Jacobs J. Fuchs E. Lymphoid enhancer factor 1 directs hair follicle patterning and epithelial cell fate. Genes Dev 1995; 9(6): 700-713, https://doi.org/10.1101/ gad.9.6.700.

58. Huelsken J., Vogel R., Erdmann B., Cotsarelis G., Birchmeier W. Beta-catenin controls hair follicle morphogenesis and stem cell differentiation in the skin. Cell 2001; 105(4): 533545, https://doi.org/10.1016/s0092-8674(01)00336-1.

59. Niemann C., Owens D.M., Hülsken J. Birchmeier W. Watt F.M. Expression of DeltaNLef1 in mouse epidermis results in differentiation of hair follicles into squamous epidermal cysts and formation of skin tumours. Development 2002; 129(1): 95-109.

60. Andl T., Reddy S.T., Gaddapara T., Millar S.E. Wnt signals are required for the initiation of hair follicle development. Dev Cell 2002; 2(5): 643-653, https://doi. org/10.1016/s1534-5807(02)00167-3.

61. Gat U., DasGupta R., Degenstein L., Millar S.E. De novo hair follicle morphogenesis and hair tumors in mice expressing a truncated betacatenin in skin. Cell 1998; 95(5): 605-614, https://doi.org/10.1016/s0092-8674(00)81631-1.

62. Lo Celso C., Prowse D.M., Watt F.M. Transient activation of beta-catenin signalling in adult mouse epidermis is sufficient to induce new hair follicles but continuous activation is required to maintain hair follicle tumours. Development 2004; 131(8): 1787-1799, https://doi.org/10.1242/dev.01052.
63. Schneider M.R., Schmidt-Ullrich R., Paus R. The hair follicle as a dynamic miniorgan. Curr Biol 2009; 19(3): R132R142, https://doi.org/10.1016/j.cub.2008.12.005.

64. Ahtiainen L., Uski I., Thesleff I., Mikkola M. Early epithelial signaling center governs tooth budding morphogenesis. J Cell Biol 2016; 214(6): 753-767, https://doi. org/10.1083/jcb.201512074.

65. Hsu Y.C., Li L., Fuchs E. Emerging interactions between skin stem cells and their niches. Nat Med 2014; 20(8): 847856, https://doi.org/10.1038/nm.3643.

66. Braun K.M., Watt F.M. Epidermal label-retaining cells: background and recent applications. J Investig Dermatol Symp Proc 2004; 9(3): 196-201, https://doi.org/10.1111/j.1087-0024. 2004.09313.x.

67. Mascré G., Dekoninck S., Drogat B., Youssef K.K., Broheé S., Sotiropoulou P.A., Simons B.D., Blanpain C. Distinct contribution of stem and progenitor cells to epidermal maintenance. Nature 2012; 489(7415): 257-262, https://doi. org/10.1038/nature11393.

68. Sada A., Jacob F., Leung E., Wang S., White B.S., Shalloway D., Tumbar T. Defining the cellular lineage hierarchy in the interfollicular epidermis of adult skin. Nat Cell Biol 2016; 18(6): 619-631, https://doi.org/10.1038/ncb3359.

69. Rompolas P., Mesa K.R., Kawaguchi K., Park S., Gonzalez D., Brown S., Boucher J., Klein A.M., Greco V. Spatiotemporal coordination of stem cell commitment during epidermal homeostasis. Science 2016; 352(6292): 1471-1474 https://doi.org/10.1126/science.aaf7012.

70. Roy E., Neufeld Z., Cerone L., Wong H.Y., Hodgson S., Livet J., Khosrotehrani K. Bimodal behaviour of interfollicular epidermal progenitors regulated by hair follicle position and cycling. EMBO J 2016; 35(24): 2658-2670, https://doi. org/10.15252/embj.201693806.

71. Merrill B.J., Gat U., DasGupta R., Fuchs E. Tcf3 and Lef1 regulate lineage differentiation of multipotent stem cells in skin. Genes Dev 2001; 15(13): 1688-1705, https://doi. org/10.1101/gad.891401.

72. Barrott J.J., Cash G.M., Smith A.P., Barrow J.R. Murtaugh L.C. Deletion of mouse Porcn blocks Wnt ligand secretion and reveals an ectodermal etiology of human focal dermal hypoplasia/Goltz syndrome. Proc Natl Acad Sci USA 2011; 108(31): 12752-12757, https://doi.org/10.1073/ pnas.1006437108.

73. Blanpain C., Fuchs E. Epidermal homeostasis: a balancing act of stem cells in the skin. Nat Rev Mol Cell Biol 2009; 10(3): 207-217, https://doi.org/10.1038/nrm2636.

74. Singh R., Chen C., Phelps R.G., Elston D.M. Stem cells in the skin and their role in oncogenesis. J Eur Acad Dermatol Venereol 2014; 28(5): 542-549, https://doi.org/10.1111/jdv.12248.

75. Clayton E., Doupé D.P., Klein A.M., Winton D.J., Simons B.D., Jones P.H. A single type of progenitor cell maintains normal epidermis. Nature 2007; 446(7132): 185189, https://doi.org/10.1038/nature05574.

76. MacDonald B.T., Tamai K., He X. Wnt/beta-catenin signaling: components, mechanisms, and diseases. Dev Cell 2009; 17(1): 9-26, https://doi.org/10.1016/j. devcel.2009.06.016.

77. Choi Y.S., Zhang Y., Xu M., Yang Y., Ito M., Peng T., Cui Z., Nagy A., Hadjantonakis A.K., Lang R.A., Cotsarelis G., Andl T., Morrisey E.E., Millar S.E. Distinct functions for Wnt/ beta-catenin in hair follicle stem cell proliferation and survival and interfollicular epidermal homeostasis. Cell Stem Cell 2013; 13(6): 720-733, https://doi.org/10.1016/j.stem.2013.10.003. 
78. Lim X., Tan S.H., Koh W.L., Chau R.M., Yan K.S., Kuo C.J., van Amerongen R., Klein A.M., Nusse R. Interfollicular epidermal stem cells self-renew via autocrine Wnt signaling. Science 2013; 342(6163): 1226-1230, https:// doi.org/10.1126/science.1239730.

79. Augustin I., Gross J., Baumann D., Korn C., Kerr G., Grigoryan T., Mauch C., Birchmeier W., Boutros M. Loss of epidermal Evi/Wls results in a phenotype resembling psoriasiform dermatitis. J Exp Med 2013; 210(9): 1761-1777, https://doi.org/10.1084/jem.20121871.

80. Watt F.M., Collins C.A. Role of beta-catenin in epidermal stem cell expansion, lineage selection, and cancer. Cold Spring Harbor Symp Quant Biol 2008; 73: 503-512, https://doi.org/10.1101/sqb.2008.73.011.

81. Klaus A., Birchmeier W. Wnt signalling and its impact on development and cancer. Nat Rev Cancer 2008; 8(5): 387398, https://doi.org/10.1038/nrc2389.

82. Kalinin A., Marekov L.N., Steinert P.M. Assembly of the epidermal cornified cell envelope. J Cell Sci 2001; 114(Pt 17): 3069-3070.

83. Senoo M., Pinto F., Crum C.P., McKeon F. p63 is essential for the proliferative potential of stem cells in stratified epithelia. Cell 2007; 129(3): 523-536, https://doi.org/10.1016/j. cell.2007.02.045.

84. Holland J.D., Klaus A., Garratt A.N., Birchmeier W. Wnt signaling in stem and cancer stem cells. Curr Opin Cell Biol 2013; 25(2): 254-264, https://doi.org/10.1016/j. ceb.2013.01.004.

85. Chan E.F., Gat U., McNiff J.M., Fuchs E. A common human skin tumour is caused by activating mutations in ß-catenin. Nat Genet 1999; 21(4): 410-413, https://doi. org/10.1038/7747.

86. Owens D.M., Watt F.M. Contribution of stem cells and differentiated cells to epidermal tumours. Nat Rev Cancer 2003; 3(6): 444-451, https://doi.org/10.1038/nrc1096.

87. Takeda H., Lyle S., Lazar A.J.F., Zouboulis C.C., Smyth I., Watt F.M. Human sebaceous tumors harbor inactivating mutations in LEF1. Nat Med 2006; 12(4): 395-397, https://doi.org/10.1038/nm1386.

88. Veltri A., Lang C., Lien W.-H. Concise review: Wnt signaling pathways in skin development and epidermal stem cells. Stem Cells 2018; 36(1): 22-35, https://doi.org/10.1002/ stem.2723.

89. Watt F.M. Stem cell fate and patterning in mammalian epidermis. Curr Opin Genet Dev 2001; 11(4): 410-417, https:// doi.org/10.1016/s0959-437x(00)00211-2.

90. Adaimy L., Chouery E., Megarbane H., Mroueh S., Delague V., Nicolas E., Belguith H., de Mazancourt P., Megarbane A. Mutation in WNT10A is associated with an autosomal recessive ectodermal dysplasia: the odontoonycho-dermal dysplasia. Am J Hum Genet 2007; 81(4): 821828, https://doi.org/10.1086/520064.

91. Liu F., Thirumangalathu S., Gallant N.M., Yang S.H.,
Stoick-Cooper C.L., Reddy S.T., Andl T., Taketo M.M., Dlugosz A.A., Moon R.T., Barlow L.A., Millar S.E. Wnt-betacatenin signaling initiates taste papilla development. Nat Genet 2007; 39(1): 106-112, https://doi.org/10.1038/ng1932.

92. Enshell-Seijffers D., Lindon C., Kashiwagi M., Morgan B.A. $\beta$-catenin activity in the dermal papilla regulates morphogenesis and regeneration of hair. Dev Cell 2010; 18(4): 633-642, https://doi.org/10.1016/j.devcel.2010.01.016.

93. Lowry W.E., Blanpain C., Nowak J.A., Guasch G., Lewis L., Fuchs E. Defining the impact of beta-catenin/Tcf transactivation on epithelial stem cells. Genes Dev 2005; 19(13): 1596-1611, https://doi.org/10.1101/gad.1324905.

94. Van Mater D., Kolligs F.T., Dlugosz A.A., Fearon E.R. Transient activation of beta-catenin signaling in cutaneous keratinocytes is sufficient to trigger the active growth phase of the hair cycle in mice. Genes Dev 2003; 17(10): 1219-1224, https://doi.org/10.1101/gad.1076103.

95. Yoon J.S., Choi M., Shin C.Y., Paik S.H., Kim K.H., Kwon O. Development of a model for chemotherapy-induced alopecia: profiling of histological changes in human hair follicles after chemotherapy. J Invest Dermatol 2016; 136(3): 584-592, https://doi.org/10.1038/jid.2015.358.

96. Gilhar A., Etzioni A., Paus R. Alopecia areata. N Engl $J$ Med 2012; 366(16): 1515-1525, https://doi.org/10.1056/ nejmra1103442.

97. MacLean K.J., Tidman M.J. Alopecia areata: more than skin deep. Practitioner 2013; 257(1764): 29-32.

98. Mitsiadis T., Barrandon O., Rochat A., Barrandon Y., De Bari C. Stem cell niches in mammals. Exp Cell Res 2007; 313(16): 3377-3385, https://doi.org/10.1016/j.yexcr. 2007.07.027.

99. Obernikhin S.S., Yaglova N.V. Spontaneous alopecia areata in offspring of murine dams exposed to immunostimulation in early pregnancy. Fundamental'nye issledovaniya 2013; 12(2): 273-278.

100. Yaglova N.V., Obernikhin S.S. Inherited alopecia areata in mice as a result of adoptive transfer of in vivo mitogen-activated splenic cells to females during early period of gestation. Bull Exp Biol Med 2015; 159(2): 285-288, https:// doi.org/10.1007/s10517-015-2943-4.

101. Yaglova N.V., Obernikhin S.S. Development of the skin and appendages of in offspring of murine dams exposed to immunostimulation in early pregnancy. Klinicheskaya $i$ eksperimental'naya morfologiya 2014; 2(10): 50-57.

102. Shapovalova Ye.Yu., Boyko T.A., Baranovskiy Yu.G., Kolomoyetz T.A., Karakulkina O.A. Cell proliferative and apoptosis activity in different areas of human skin in early embryonic histogenesis. Mezhdunarodnyy nauchnoissledovatel'skiy zhurnal 2015; 7-5(38): 71-74.

103. Shapovalova Ye.Yu., Boyko T.A., Baranovskiy Yu.G., Karakul'kina O.A. Prenatal histogenetic prerequisites of regional differences in human skin development. Morfologia 2016; 149(3): 235. 